\title{
Approaches Of Increasing Financial Literacy Of The Population During The Economic Digitalization In Uzbekistan
}

\author{
${ }^{1}$ Farkhod Ozodovich Abdullaev, ${ }^{2}$ Nurulla Bakhromovich Fayzullaev \\ ${ }^{1}$ Director of the Urgench branch of the Academy of Public Administration under the President of the Republic of Uzbekistan. \\ ${ }^{2}$ Head of the Department of Accounting and Auditing, Faculty of Tourism and Economics, Uzbekistan.
}

\begin{abstract}
This article analyzes the importance of financial literacy of the population in the process of transition to the digital economy. The article also analyzes people's behavior with financial activities and processes, the level of financial literacy in developing and developed countries and gives recommendations and proposals which are directing at increasing the financial literacy level within the country.
\end{abstract}

Keywords:

finance, development, budget, income, economic digitalization, market institutions.

Article Received: 18 October 2020, Revised: 3 November 2020, Accepted: 24 December 2020

\section{Introduction}

Nowadays, one of the most important tasks for the further development of Uzbekistan is to achieve economic digitalization in the country. This further development, in turn, requires both economic and social measures to carry out within the country. That is to say, economic development is not only physical changes of nations environment but also changes in the way people think and behave. Thus during the process of digital transformation of market institutions the literacy level of the population, to be more precisely, increasing the level of financial literacy will be the objective character due to wide range of online transactions in the digitalized world.

In his address, the President of the Republic of Uzbekistan Shavkat Mirziyoyev for the first time put forward the concept of poverty in Uzbekistan [1]. President also said "the greatest poverty is the lack of knowledge". It can also be assumed that he emphasizes the level of financial literacy. Previously, the concept of poverty level in the country was almost never used. At one of the meetings, President Shavkat Mirziyoyev noted that $12-15 \%$ of the population of Uzbekistan, or 45 million people, live in poverty. This means that their daily income does not exceed 10-13 thousand soums (about 0,95-1.25 US dollars).
On August 17, 2018, the Board of the Central Bank of Uzbekistan decided to join the Alliance for Financial Inclusion. The alliance was established in 2008 to help member countries develop and implement fiscal policy, establish and train working groups on topical issues of banking services, create a platform for exchange of experience, protect consumer rights and finance small business.

In Uzbekistan, only two methods are used to measure poverty. The results of the nutritionbased method show that the poverty rate is $11.4 \%$. Based on the results of the second approach, the poverty rate is $36.6 \%$ at $\$ 5.5$ per day and $9.6 \%$ at $\$$ 3.6. According to the World Bank, by regions of Uzbeksitan high levels of poverty are observed in Samarkand, Surkhandarya, Syrdarya, Andijan regions and the Republic of Karakalpakstan[2].

In recent years, significant progress has been made in creating a publicly accessible database that can be used to study poverty levels. They allow us to describe poverty, its factors, as well as test many hypotheses about the impact of specific programs and political reforms on poverty. For example, by comparing the characteristics of poor and non-poor people or households, it is possible to identify the cause of poverty and set clear parameters to combat it. In this case, the 
information can be analyzed in the following areas [table 1]:

\section{Materials and methods}

These results confirm the importance of quality of education, employment rate, housing opportunities and living conditions in most regions of the country in addressing the problem of poverty. The quality of education can also be attributed to financial literacy. The lower the level of financial literacy of the population, especially the youth, the higher the level of poverty in the country.
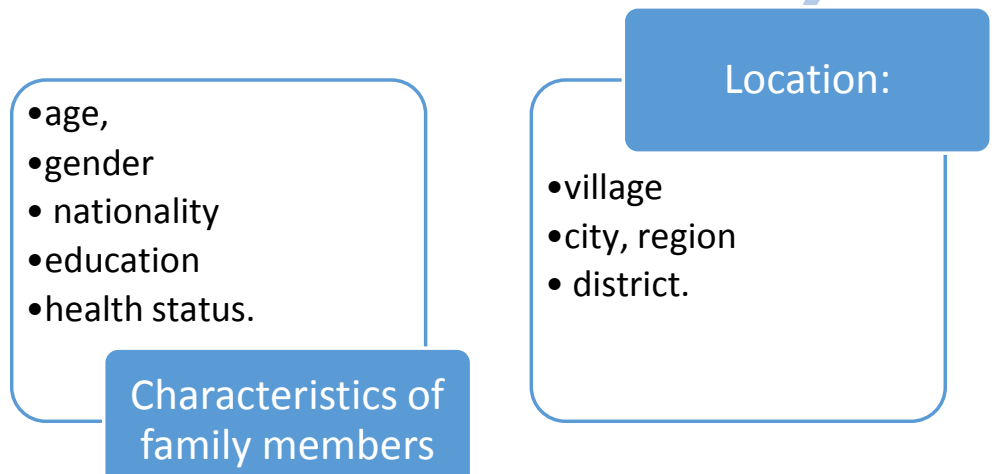

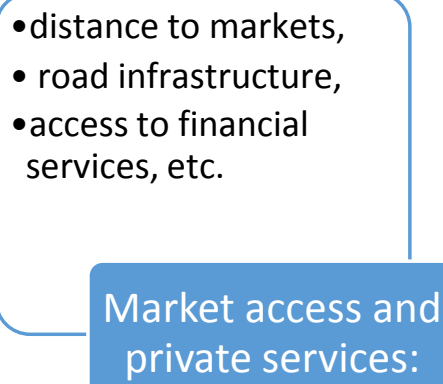

Table 1. Indirect factors influencing the measurement of poverty.

Low level of financial literacy is not only associated with developing countries but also with developed countries so that both of them always take actions to make their population financially literate because of unprecedented benefits to both individuals and the economy as a whole. Most countries such as USA, Canada, and The United Kingdom, along with international organizations like the OECD (The Organization for Economic Co-operation and Development) are concerned with particular measures to improve financial literacy level in the countries and have launched various programs aimed at tackling problems the governments face. For instance, the OECD started the International Gateway for Financial Education which focuses to perform as a clearinghouse for financial education programs, information and research worldwide [1].There is a national nonprofit organization on financial literacy the JumpStart Coalition for Personal Financial Literacy in the U.S., consists of corporate, academic, non-profit, and government organizations. The mission of this organization is to help young people develop lifelong financial decision-making skills. The UK also has a special body - the Money Advice Service which develops and coordinates national strategies to develop the financial capability of the population. The process of raising financial literacy in Singapore is slightly different from other countries. The country has the inaugural Financial Literacy Hub for Teachers established by the National Institute of Education Singapore and government-funded the Institute for Financial Literacy [2]. The aim of these organizations is to provide free and effective education-oriented financial programs to the population in order to build financial capability in the country.

Improving the level of financial literacy of the population is usually carried out by special government departments or organizations funded by the state. For example, in the United States, this responsibility is vested in the Financial Literacy and Education Commission (FLEC). 
Australia has a Financial Information Service (FIS), Canada has a Financial Consumer Protection Service (FCAC), and the UK has a Financial Services Authority (FSA).

As for the experience of the United States in this regard, then they, being a state with the largest financial center in the world - New York, have a wealth of experience in improving the financial literacy of the population. The Financial Literacy and Eduction Commission (FLEC) was formed in collaboration with the US Congress. In 2006, the National Financial Literacy Strategy was developed. But do not forget that since 1995 the "JumpStart" Coalition for Individual Financial Literacy has been operating in the United States, which provides assistance to young people under the age of 19 [3].

In general, in the United States, there is almost the same vector of measures to ensure financial literacy as in other developed countries:

- emphasis on an individual approach;

- creation of telephone lines for financial matters;

- instilling financial skills in children in schools.

But the United States has achieved more significant results: financial literacy in the country is at a high level. Here, children can receive a bank card at the age of 10, in most states the turnover of cash is minimized, there is a greater integration of the population into the financial sphere of society. A 2010 study by the "JumpStart" Coalition found that only 21 states need specific financial education. This is a big breakthrough, since in 2008 a significant part of the country's young population needed additional financial education. In the United States, it is also customary to set up so-called financial centers at universities, where students can obtain the information they need for financial transactions both during their studies and after graduation.

China recognizes the leading role of the state in raising the level of the financial culture of the population. However, the PRC currently lacks a unified state program aimed at improving financial literacy. We can only note the efforts of individual authorities in this area. These include the development of the Student Financial Literacy Program (CIEFR) [4].

This program was developed jointly by the Ministry of Education and the Ministry of Finance of China. Its purpose is to disseminate information among schoolchildren and students about the possibility of obtaining educational loans, as well as help those students who have difficulties in paying off educational loans. In addition, the Ministry of Finance, together with the Ministry of Education, established an educational institution based at Peking University, which combines the functions of a national research center in the field of economics and finance, as well as an educational center that develops programs to improve financial literacy of the population. This allows this educational institution to conduct its courses on improving the financial culture of the population in accordance with global trends in this area, as well as the main socio-economic goals of the country.

In Brazil, the National Strategy for Improving the Quality of Financial Education (ENEF) is currently in place at the state level. It was developed by the committee for the regulation of financial markets, the ministries of education, finance, justice, social protection, as well as largest banks and credit organizations in the country[5].

When developing the ENEF program, the authors took into account that about $82 \%$ of citizens of the country did not know the exact percentage of their loans, and $87 \%$ had no savings or had little or no savings. Therefore, the goals were to increase the involvement of the population in the activities of financial markets, as well as to increase the financial literacy of all segments of the population.

A feature of this program is the coverage of a large part of society, and not a specific category of citizens. For example, ENEF includes measures to improve the financial literacy of students. These include: teacher training based on materials and curricula developed by the Central Bank of Brazil; development of textbooks and multimedia 
programs on this topic for different age categories of students. The pilot project, launched in 2010, reached 30,000 students across the country. This project was recognized as successful at the government level.

As for the possibility of applying these measures in Uzbekistan, some of them have rather good prospects, which is explained by the similarity of China and Brazil in terms of the level of financial literacy of the population.

The importance of financial literacy comes from its numerous benefits to the population of the country[6].

When we say about basic financial knowledge, it means being aware of the followings:

- Insurance;

- Credit;

- Budgeting;

- Saving;

- Debt;

- Interest;

- Risk and etc.

Having basic financial knowledge is so important for a person to achieve financial stability. The individual is able to manage his or her current budget properly, use his/her income wisely to meet his current and future needs, and make effective financial decisions in the socioeconomic processes throughout life, that is to say, he or she develops the ability to manage money and become accustomed to control it wisely. In short, under the scarce resources in the economy, people will learn to use their income to maximize their needs by increasing their financial knowledge. Unfortunately, in many cases, individuals face problems in managing their available money income (incorrect spending) due to lack of sufficient financial skills and knowledge[7]. Inefficient decisions in spending affects people's mood, causes a stress andmaybe the reason for other help problems occur.

Alessandro Antoniette, Borsette Adrea describe financial literacy as "the process by which people improve their understanding of financial products and concepts and, through information, instruction and advice, develop the skills and confidence to become more aware of financial risks and opportunities, to make informed choices, to know where to go for help, and take other effective actions to improve their financial well-being" [8].

Thomas Retzmann and Gunther Seeber consider financial literacy as the application of skills in dealing with routine money and financial matters, such as making a withdrawal or filling out a transfer order [9].

According to the research results of Annamaria Lusardi and Olivia Mitchell, financial literacy determines how well people make and execute financial decisions, including saving, investing, borrowing from one's retirement account, and planning for retirement[10].

Norman King, in his article, defines that financial literacy is the ability to understand finance, more specifically, it refers to the set of skills and knowledge that allow an individual to make informed and effective decisions through their understanding of finances[11].

\section{Result and discussion}

Based on world experience, significant experience in the development of financial education in four regions of Uzbekistan with high poverty rates is proposed as following table. It is aimed at acquiring the skills of financial literacy of more than 1 million people until 2024. To do this, authors proposed to create a special website for financial literacy, on which materials on budgeting, savings, the use of bank cards, banking services, and debt management are posted; The web site also offers a variety of financial games. A study of the activities foreseen by this financial literacy programs in individual regions will make it possible to summarize the main aspects of their implementation[table 2]. 
Table 2. Proposed financial literacy programs in separate regions of Uzbekistan.

\begin{tabular}{|c|c|c|c|}
\hline $\begin{array}{c}\text { Region of Uzbekistan } \\
\text { with high levels of } \\
\text { poverty }\end{array}$ & Implementation toolkit & For whom & Purpose \\
\hline $\begin{array}{c}\text { Samarqand region } \\
\text { (2021-2022 year) }\end{array}$ & $\begin{array}{l}\text { Elaboration of the concept } \\
\text { of financial literacy through } \\
\text { cooperation with } \\
\text { educational institutions and } \\
\text { the inclusion of financial } \\
\text { literacy in the curriculum of } \\
\text { schools, colleges and } \\
\text { universities }\end{array}$ & $\begin{array}{l}\text { Educators and } \\
\text { students }\end{array}$ & $\begin{array}{l}\text { To pay attention to the } \\
\text { problem of low financial } \\
\text { literacyamong } \\
\text { youngpeople; } \\
\text { teachunderstandingvarious } \\
\text { aspects of budget } \\
\text { planning,savings and } \\
\text { credit management }\end{array}$ \\
\hline $\begin{array}{l}\text { Surkhandarya region } \\
\qquad(2020-2022)\end{array}$ & $\begin{array}{l}\text { Programs, united by a single } \\
\text { motto "Financial literacy } \\
\text { throughout life": "Youth } \\
\text { Banking" program, a } \\
\text { program for educating older } \\
\text { banking people on new } \\
\text { banking technologies. With } \\
\text { the support of business } \\
\text { structures, a significant } \\
\text { number of youth websites } \\
\text { and portals will be created } \\
\text { that contain tips, successful } \\
\text { stories in the field of } \\
\text { personal finance } \\
\text { management, which use } \\
\text { modern technology. }\end{array}$ & $\begin{array}{l}\text { Different } \\
\text { layers of the } \\
\text { region }\end{array}$ & $\begin{array}{l}\text { Reduction of financial } \\
\text { illiteracy of the population } \\
\text { of the region }\end{array}$ \\
\hline $\begin{array}{c}\text { Syrdaryaregion (2020- } \\
\text { 2022) }\end{array}$ & $\begin{array}{l}\text { Creating an independent } \\
\text { fund and the program "Your } \\
\text { expenses, your savings, } \\
\text { your future: a guide for } \\
\text { beginners"; resources offer } \\
\text { a large collection of } \\
\text { educational materials to } \\
\text { help in organizing and } \\
\text { conducting the financial } \\
\text { literacy program. }\end{array}$ & $\begin{array}{l}\text { Various target } \\
\text { groups }\end{array}$ & $\begin{array}{l}\text { To promote the formation } \\
\text { of a positive attitude and } \\
\text { responsible effective } \\
\text { behavior in relation to } \\
\text { money at a young age. }\end{array}$ \\
\hline $\begin{array}{c}\text { Andijanregion (2020- } \\
\text { 2022) }\end{array}$ & $\begin{array}{l}\text { Conducting demonstration } \\
\text { events (presentations and } \\
\text { interactive shows), where } \\
\text { the audience received basic } \\
\text { financial skills, such as } \\
\text { budget planning, opening a }\end{array}$ & $\begin{array}{l}\text { Local } \\
\text { companies, } \\
\text { municipalities, } \\
\text { universities, } \\
\text { colleges, high } \\
\text { school }\end{array}$ & $\begin{array}{l}\text { Achieving on banking } \\
\text { services understandable } \\
\text { and affordable for people } \\
\text { in the Andijan region's } \\
\text { districts }\end{array}$ \\
\hline
\end{tabular}


bank account, as well as

information on the security

of payment systems. students

[1] President Shavkat Mirziyoyev's Address to the Oliy Majlis

24.01.2020 https://president.uz/en/lists/view/3324

[2] B. Khamidov, Poverty rate in Uzbekistan. What can be done to reduce poverty? Analysis. https://review.uz

[3] Mandell, L. and Klein, L.S., 2007. Motivation and financial literacy. Financial services review, 16(2).

[4] 崔颖 and 郭磊, 2015. 高职学生理财教育模式研究.

湖北经济学院学报 (人文社会科学版), 2(2).

\section{Conclusion}

Model of proposed financial literacy programs in separate regions of Uzbekistan (table 2) above is the such kind of model which can be used in the formation of state programs, road maps and other concepts aimed at increasing the financial literacy of the population.

Financial literacy of the population is a qualitative indicator that ensures that everyone in society has sufficient economic knowledge, skills and abilities, values and the right approach to making economic decisions based on them, which allows them to ensure their own well-being.

The level of development of the country's economy has a positive impact on the level of financial literacy of the population. However, this does not mean that there are no problems in this area in developed countries. Accordingly, regardless of the level of development, it is important that each country develops regular and systematic measures to increase the level of financial literacy of the population, based on the characteristics of their economy and population mentality.

The higher the level of financial literacy of the population, the higher the level of stability and prosperity, first of all, the person, the region in which he lives, and the whole national economy.
[5] Bruhn, M., de Souza Leão, L., Legovini, A., Marchetti, R. and Zia, B., 2013. The impact of high school financial education: Experimental evidence from Brazil. The World Bank.

[6] "International Gateway for Financial Education Home". www.financialeducation.org

[7] "The MoneySENSE Singapore Polytechnic Institute For Financial Literacy". finlit.sg.

[8] Antonietti, Alessandro \& Andrea, Borsetto \& Iannello, Paola. (2016). A Metacognitive Approach to Financial Literacy. 10.1007/978981-10-0360-8_5.

[9] Seeber, Günther \& Retzmann, Thomas. (2016). Financial Education in General Education Schools: A Competence Model. 10.1007/978-981-10-0360-8_2.

[10] Lusardi, Annamaria and Mitchell, Olivia S., The Outlook for Financial Literacy (May 2011). NBER Working Paper No. w17077. Available at SSRN: https://ssrn.com/abstract=1848592

[11] King, Norman. (2010). Importance of financial education in making informed decision on spending. Journal of Economics and International Finance. 2. 199-207.

\section{REFERENCE}

